\title{
PREDICTION OF TECHNOLOGICAL PARAMETERS OF SHEET METAL BENDING IN TWO STAGES USING FEED-FORWARD NEURAL NETWORK
}

\author{
Jernej Senveter, Joze Balic, Mirko Ficko, Simon Klancnik
}

Original scientific paper

This paper describes sheet metal bending in two stages as well as predicting and testing of the final bend angle by means of a feed-forward neura network. The primary objective was to research the technological parameters of bending sheet metal in two stages and to develop an intelligent method that would enable the predicting of those technological parameters. The process of bending sheet metal in two stages is presented by demonstrating the various technological parameters and the test tool used to carry out tests and measurements. The results of the tests and measurements were of decisive guidance in the evaluation of individual technological parameters. Developed method for prediction of the final bend angle is based on a feed-forward neural network that receives signals at the input level. These signals then travel through the hidden level to the output level, where the responses to input signals are received. The input to the neural network is composed of data that affect the selection of the final bend angle. Only five different inputs are used for the total neural network. By choosing the desired final bend angle by means of the trained neural network, bending sheet metal in two stages is optimised and made more efficient.

Keywords: bending in two stages; intelligent system; neural network; prediction of the final bend angle

\section{Predviđanje tehnoloških parametara savijanja lima u dvije faze pomoću usmjerene neuronske mreže}

Izvorni znanstveni rad

Članak prikazuje savijanje lima u dvije faze i predviđanje konačnog kuta savijanja pomoću usmjerene neuronske mreže. Glavni cilj je bio istražiti tehnološke parametre savijanja lima u dvije faze i razviti inteligentan način, koji će omogućiti predviđanje tih tehnoloških parametara. Prikazan je proces savijanja lima u dvije faze, gdje se prikazuju i razni tehnološki parametri i ispitni alati sa kojima su provedena ispitivanja i mjerenja. Rezultati ispitivanja i mjerenja su bili ključ u donošenju procjene pojedinih tehnoloških parametara. Opisano je predviđanje konačnog kuta savijanja lima korištenjem usmjerene neuronske mreže, koja prima signale na ulazu. Ti signali tada prolaze kroz skrivenu razinu do izlaza, gdje dobiju odgovor na ulazne signale. Za ulaz u neuronsku mrežu upotrebljavaju se podaci koji utječu na odabir kuta konačnog savijanja. Za neuronsku mrežu se koristi pet različitih inputa. Odabirom željenog kuta savijanja pomoću neuronske mreže, može se doprinijeti optimizaciji savijanja lima u dvije faze.

Ključne riječi: inteligentni sustav; neuronske mrě̌e; predviđanje konačnoga kuta savijanja; savijanje u dvije faze

\section{Introduction}

This paper elaborates the problem of achieving a sheet bending angle of $90^{\circ}$ upon springback in combined forming tools according to the process of bending sheet metal in two stages. By the initial bend, in the process of bending sheet metal in two stages, sheet metal is predeformed to an angle $\alpha_{1}{ }^{\prime}$, which then along with the punch moving toward the die allows bending angle greater than $90^{\circ}$ or compensation for the springback of the sheet metal[1]. The method of bending sheet metal in two stages consists of two operations, which are carried out in two successive working strokes of the bending tool [1]. The developed method provides, on the basis of the obtained experimental data, simulation and prediction of the technological parameters of the bending process.

A bending angle of a $90^{\circ}$ bend is very often required in progressive tools but difficult to attain in practice due to the phenomenon of springback of sheet metal [1]. It is known from the theory that the mentioned angle is more difficult to achieve, and angles greater than $90^{\circ}$ are impossible to make in a single step with only one bending of the sheet metal [1]. The level of springback depends on each material separately. In those materials which are now mostly used for such products it amounts to around $2^{\circ}$ to $5^{\circ}[1 \div 3]$. The springback effect is a result of a reversible elastic strain recovery that takes place when the tools are removed and the unloading of the formed part completed [4].

Pahole et al. [1] among the first described and implemented the method of sheet metal bending in two stages for $90^{\circ}$ angle and more. Thus, bending in two stages results in bending at an angle of $90^{\circ}$ according to the "tractrix" principle. The idea of an unknown author has been developed and used for bending angles greater than $90^{\circ}[1,2]$. Although the name of the method contains the notion of the "tractrix" curve on the active edge of the punch, the respective curve was not used but only its approximation [1]. Therefore, it can be concluded that the bending at a $90^{\circ}$ angle according to the "tractrix" principle bears certain similarities to wipe bending $[5 \div 8]$.

An important aspect for an adequate application of the method was also a developed and manufactured test tool for bending sheet metal. Various types of sheet metal have undergone testing on the test tool. When monitoring the process of sheet metal bending, the parameters were measured and recorded as follows: pre-bending angle, die shift in the second bend, sheet thickness, yield strength, tensile strength and the final bend angle. After a thorough analysis and verification of the measured parameters and by using the artificial intelligence-neural network, an intelligent method was implemented in order to predict the final bend angles in the process of bending sheet metal in two stages.

In 1958, Gardiner [9] already established a generalised mathematical assessment of correction of material springback for bending of various materials [10]. The work of Gardiner was continued in 1981 by Johnson and $\mathrm{Yu}$ [11] who discussed the theoretical analysis of elasto-plastic bending of a rectangular plate about two axes. An experimental study on edge flanging of sheet metal, also called wipe bending, was conducted by Davies 
and Liu [12]. A model for flanging straight edges was developed by $\mathrm{N}$. Wang [13], [10]. By making a more extensive use of the finite element method (FEM) for studying and researching sheet metal forming, Nagtegaal and Taylor [14] designed a very effective way of controlling and monitoring of the calculation of material springback by an implicit method [10]. Livatyali and Altan [15] designed a computer-aided method for straight flanging of sheet metal with the help of the finite element method. Ling, Lee and Cheok [10] found out that the geometry, that is the form of the tool for separate products, experiences many iterations and simulations in the stage of searching for and eliminating errors before attaining a geometry which is satisfactory and adequate.

Thus, the main objective of the paper is to discuss the presented bending to an angle of $90^{\circ}$ and the developed intelligent method for predicting the final bend angle.

\section{Description of the process of sheet metal bending in two stages}

It is evident from Fig. 1 that sheet metal is bent to an angle of about $45^{\circ}$ during the first step, and to its final dimension during the second step. With an appropriate spacing between the second die and the punch it is assured that the sheet metal, i.e. the workpiece, is bent in the first step in the area which is then "drawn" around the bend radius in the second step [1].

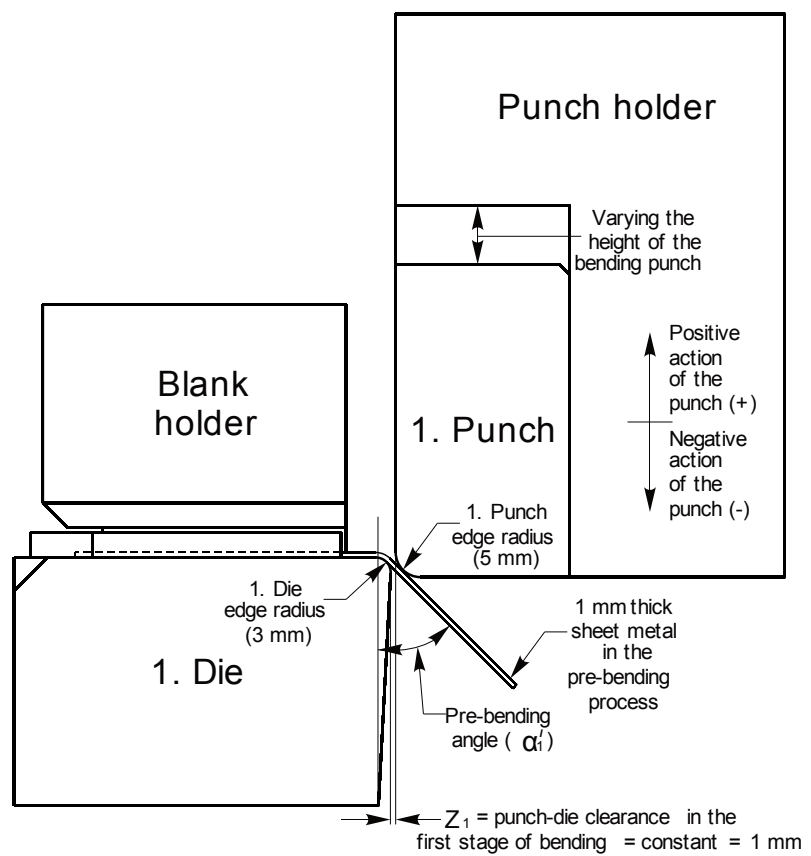

Figure 1 The first stage of bending (i.e. pre-bending) with the presented basic parameters of the tool in the first bend

In the second step, it is necessary to provide for clearance in order to bend the sheet metal to an angle greater than $90^{\circ}$; this is the negative angle on the die [1]. The mentioned withdrawal or release of the second die ensures that the sheet metal part can be bent over the required angle and then, after unloading and elastic springback, obtain the required dimension (Fig. 2). By varying the height of the bending punch, the size of the desired pre-bending angle can be controlled quickly and effectively (Fig. 1). In the second step, the punch always moves over the bending radius, so that at this stage, the very pre-bending angle is not set [1].

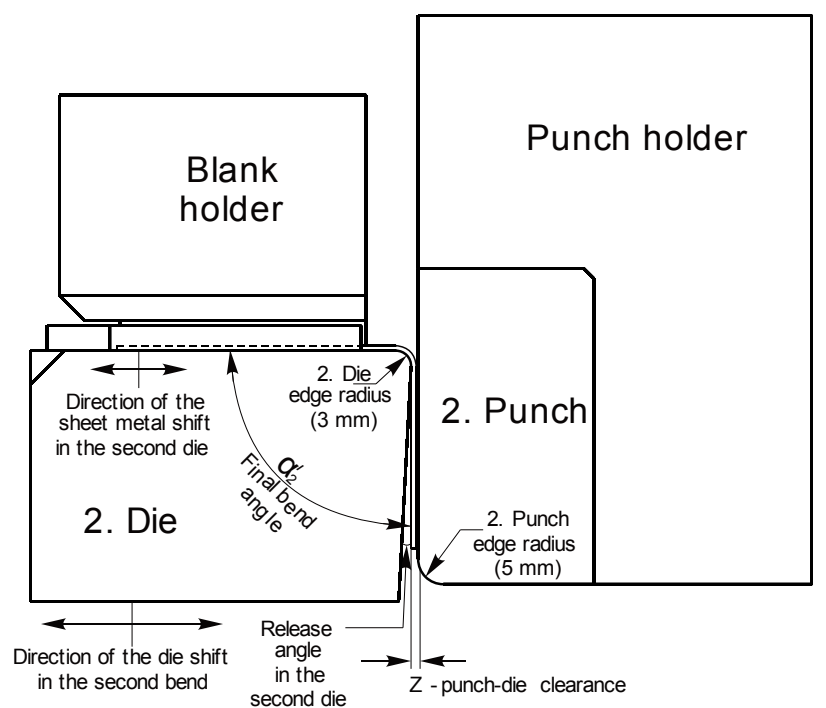

Figure 2 The second stage of bending with the presented possible directions of the shift of the second die and the shift of the sheet metal in the second die

When analysing the method, it is assumed that the shape of the punch curve has no significant impact on the final result. Other authors have stated in their analyses of springback in sheet metal forming that friction does not significantly affect springback, but the radius of the die and the clearance between the punch and the die are the ones having the greatest impact [10]. Greater clearances between the punch and die mean more springback(s) of sheet metal. Smaller clearances between the punch and the die, on the other hand, cause more internal stress of the sheet metal piece, which reduces the relative influence of the elastic deformation $[1,10]$.

The operation of bending sheet metal in two stages consists of two operations, which are carried out in two successive working strokes of the bending tool[1]:

- Pre-bending - bending to the angle $\alpha_{1}^{\prime}$. The stroke of the bending punch is adjusted in order to attain the desired pre-bending angle $\alpha_{1}{ }^{\prime}$.

- Final bending - bending at a changed position of the bending punch and the die.

The angle of the first bend $\alpha_{1}{ }^{\prime}$ and the punch-die clearance $Z$ in the area between the bending punch and the die in the second bend may be adjusted, resulting from the geometries of active parts of the tooling. Insufficient clearance between the punch and the die is not recommended, whilst the maximum value of the clearance is selected for the largest possible bending angles. It is relatively simple to adjust the bending angle $\alpha_{1}{ }^{\prime}$ without having to significantly adapt the tool. The angle $\alpha_{1}{ }^{\prime}$ is controlled by the stroke of the bending punch, whilst the angle of the second bend $\alpha_{2}{ }^{\prime}$ is controlled by the clearance $Z[1]$.

\section{Test tool for sheet metal bending in two stages}

The test tool for testing sheet metal bending in two stages was purpose-designed. The purpose of its design is 
mainly reflected in its applicability for testing and verifying sheet metal bending in two stages. Firstly, the design of the test tool was prepared. Technical literature and scientific articles were consulted dealing mainly with the wipe bending of sheet metal $[16,17]$. Basically, the tool consists of upper and lower parts.

The successful designing of the tool was followed by its construction. The test tool was designed using the CATIA V5R20 software package. The test tool is divided into upper and lower die shoes. In order to facilitate differentiation, the upper shoe of the test tool is further divided into fixed and moving parts. Fig. 3 shows the model of the test tool for bending sheet metal over two stages.

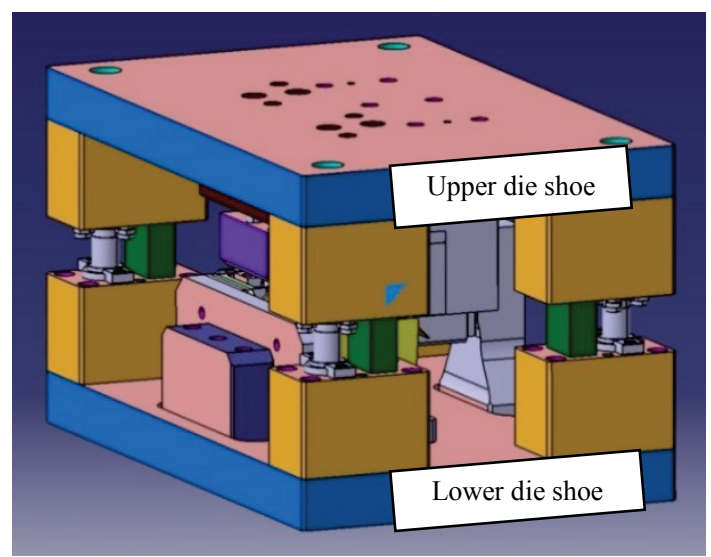

Figure 3 Design of the test tool model from an isometric view

After successfully completing the assembly of the upper shoe of the test tool for bending in two stages and the previously completed assembly of the lower shoe of the test tool, an initial testing of the tool and then testing of sheet metal bending were carried out (Fig. 4).

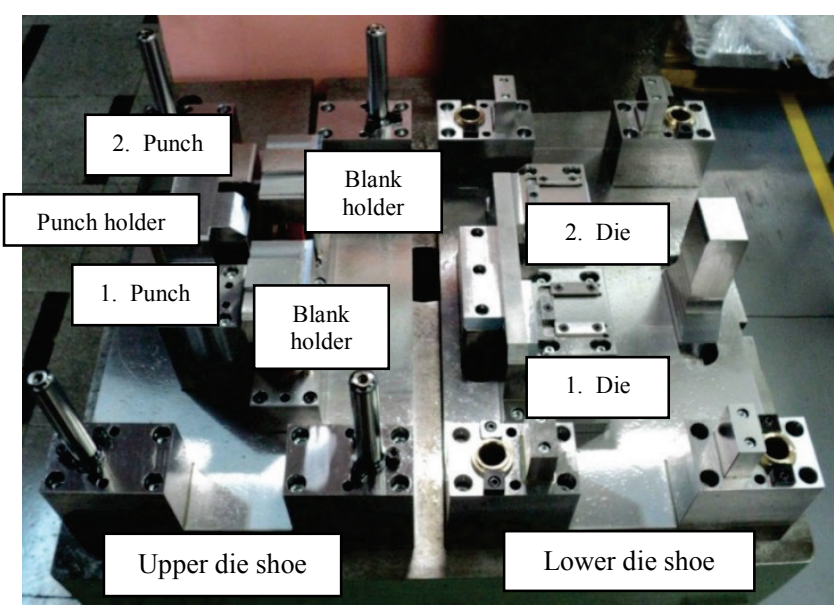

Figure 4 The upper and lower shoes of the tool before testing the sheetmetal pieces during the process of bending in two stages

\section{Tests and measurement results}

This section describes the tests performed on the test tool for bending sheet metal in two stages. A total of 68 tests were carried out on four types of sheet steel. The test pieces of the sheet metal were bent using a hand-press. The measuring devices used for measuring the individual parameters of the tests were: a digital movable measuring tool, protractor and occasionally also micrometres for separate measuring ranges. The accuracy of the digital movable measuring tool was $0.005 \mathrm{~mm}$, of the protractor $0,01^{\circ}$, and of the micrometers between $0,001 \mathrm{~mm}$ and $0,01 \mathrm{~mm}$.

When testing the sheet metal bending in two stages, four important elements were measured or determined as follows:

- height of the first punch during pre-bending,

- pre-bending angle,

- shift of the second die during the final bending stage, and

- $\quad$ measuring of the final bend angle.

The experiments were divided into two phases. The first phase included determining the appropriate height of the first punch and consequently the desired pre-bending angle. During the second phase, the optimal clearances of the second die were sought for, in order to obtain the specified final bend angles. The optimum clearance of the second die in a given case means a clearance between the punch and the die in the second bending stage by which the final bend angle of $90^{\circ}$ is achieved.

Table 1 Strength characteristics of martensitic steel SSAB Docol 1200M [18], steel sheet DC06 [19], micro-alloyed steel HX340LAD [20] and steel sheet DX $52 \mathrm{D}+\mathrm{Z}$ [19]

\begin{tabular}{|c|c|c|c|c|c|}
\hline Marking & 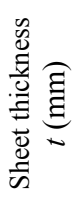 & 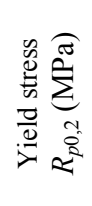 & 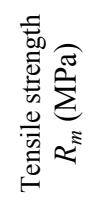 & 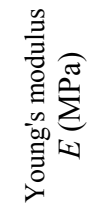 & 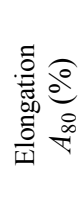 \\
\hline Docol 1200M & 1 & 1128,1 & 1326,8 & 200,000 & 3 \\
\hline $\begin{array}{c}\text { DC06_00mm16_ } \\
\text { std }\end{array}$ & 1,5 & 152 & 298,4 & 195,000 & 41 \\
\hline HX340LAD & 0,8 & 323 & 433,7 & 210,000 & $\geq 21$ \\
\hline DX $52 \mathrm{D}+\mathrm{Z}$ & 1 & 140 & 270 & 195,000 & 26 \\
\hline
\end{tabular}

Various sheet thicknesses: $0.8 \mathrm{~mm}, 1 \mathrm{~mm}, 1.2 \mathrm{~mm}, 1.5 \mathrm{~mm}$

$+0,5$
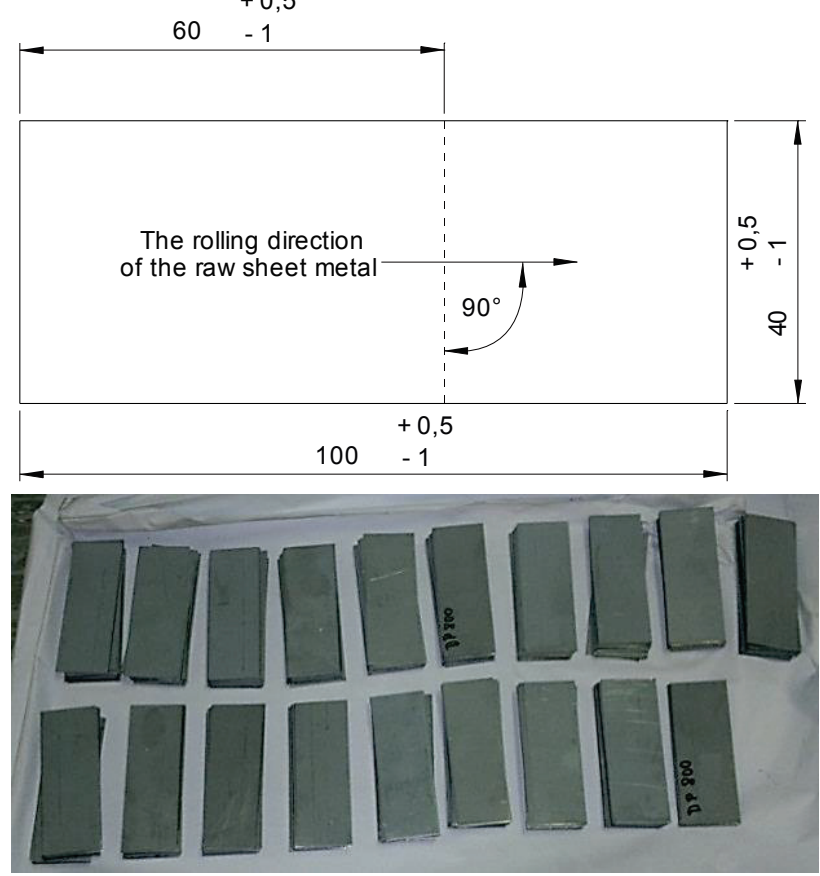

Figure 5 Dimensions of sheet-metal parts and illustration of test sheetmetal parts before testing them on the test tool 
The tests for the development of intelligent simulation for predicting sheet metal bending in two stages were carried out on the basis of a minimum number of experimental data obtained on four types of metal: SSAB Docol 1200M, DC06, HX340LAD and DX 52 D + $\mathrm{Z}$ (Tab. 1).

As illustrated in Fig. 5, sheet-metal parts with dimensions of $100 \times 40 \mathrm{~mm}$ and various thicknesses were inserted into the test tool. At a length of $60 \mathrm{~mm}$ from the starting edge of the sheet-metal part the radius was $3 \mathrm{~mm}$, resulting in the process of bending sheet metal in two stages on the test tool (Fig. 5).

The measured pre-bending angles during the first stage of bending individual test sheet-metal parts ranged between $9^{\circ}$ and $83,5^{\circ}$. A total of 68 pre-bends of test sheet-metal parts were carried out and later the same number of bends over the second stage.

During the second bending stage, three values were measured: the final bend angle, the shift of the second die and the shift of sheet metal in the second die. These data were recorded on the test sheet metal parts (Tab. 2).

Table 2 The more relevant test results of bending over two stages for different types of sheet metal

\begin{tabular}{|c|c|c|c|c|c|c|}
\hline Material & $\alpha_{1}{ }^{\prime}\left(^{\circ}\right)$ & $Z(\mathrm{~mm})$ & $t(\mathrm{~mm})$ & $R_{p 0,2}(\mathrm{MPa})$ & $R_{m}(\mathrm{MPa})$ & $\alpha_{2}{ }^{\prime}\left(^{\circ}\right)$ \\
\hline $\begin{array}{c}\text { Docol } \\
\begin{array}{c}1200 \mathrm{M} \\
(1 \mathrm{~mm})\end{array}\end{array}$ & 65,2 & 3,9 & 1 & 1128,1 & 1326,8 & 90,4 \\
\hline $\begin{array}{c}\text { DC06 } \\
(1,5 \mathrm{~mm})\end{array}$ & 50,6 & 3,45 & 1,5 & 152 & 298,4 & 90,25 \\
\hline $\begin{array}{c}\text { HX340LAD } \\
(0,8 \mathrm{~mm})\end{array}$ & 58,2 & 2,8 & 0,8 & 323 & 433,7 & 90,00 \\
\hline $\begin{array}{c}\text { DX 52 D } \\
+Z(1 \mathrm{~mm})\end{array}$ & 45,0 & 2,9 & 1 & 140 & 270 & 90,00 \\
\hline
\end{tabular}

\section{Predictions of technological parameters of sheet metal bending in two stages}

The use of a neural network when predicting the technological parameters of sheet metal bending over two stages was influenced by a number of factors. The first factor was that there was no analytical formula available for predicting technological parameters, which would predict the final results of the process on the basis of influential quantities. The neural network has proven itself to be a good tool for searching and predicting the technological parameters of bending over two stages, which is substantiated below. This study also addresses the complex problem of bending sheet metal over two stages, which has not yet been described analytically or investigated in detail.

Therefore, a neural network was designed to select the final angle of the bend under a specified pre-bending angle, die shift in the second bend, sheet thickness, yield strength and tensile strengths of each part. The objective of the neural network was to choose the optimum value of the final bend angle within the given parameters. The neural network has one output - that is an adequately selected final bend angle after unloading. As the input to the neural network, data affecting the selection of the final bend angle are used on the process of bending over two stages.

For the neural network, five different inputs are used altogether marked $\alpha_{1}{ }^{\prime}, Z, t, R_{p 0,2}$, and $R_{m}$. The inputs to the neural network and their markings are shown in Tab. 3.

Table 3 Overview of inputs to the neural network

\begin{tabular}{|c|c|}
\hline Input marking & Meaning \\
\hline$\alpha_{1}{ }^{\prime}$ & pre-bending angle in $\left(^{\circ}\right)$ \\
\hline$Z$ & die shift in the $2^{\text {nd }}$ bend in $(\mathrm{mm})$ \\
\hline$t$ & sheet metal thickness in $(\mathrm{mm})$ \\
\hline$R_{p 0,2}$ & yield stress in $(\mathrm{MPa})$ \\
\hline$R_{m}$ & tensile strength in $(\mathrm{MPa})$ \\
\hline
\end{tabular}

The final bended angle $\alpha_{2}^{\prime}$ is the angle obtained during the second stage of bending, which represents the last stage of bending over two stages. For the final bend angle, the values were measured within the range of $77,2^{\circ}$ to $93,3^{\circ}$. When further testing the system for simulation and prediction using the neural network, the relevant values for setting the tool parameters were sought after. These were the values required to obtain the $90^{\circ}$ final bend angle. Within the system for simulating and predicting the final bend angle using the neural network, the mentioned angle acted as an output.

The die shift $Z$ during the second bending stage represents the shift of the second die depending on the location of the sheet bend, and thus an input to the neural network. The value of the shift during the second bending stage is considered in a way that the shift of the second die is added the value of the movement of sheet metal in the second die. The values of the die shift in the second stage of bending ranged from $2,65 \mathrm{~mm}$ and up to 3,95 $\mathrm{mm}$.

The pre-bending angle $\alpha_{1}{ }^{\prime}$ is attained upon the first stage of bending. The respective angle is set by the height of the stroke of the first punch. Die shift $Z$ at the second bending stage represents the clearance between the second die and the second punch which is also the input to the neural network. Sheet metal thickness $t$ represents the input to the neural network, too. Settings of various sheet metal holders on the test tool are mainly affected by the thickness of sheet metal. The penultimate input to the neural network is yield stress $R_{p 0,2}$ defined for each material separately. In general, lower yield stress allows for an easier initial plastic deformation of sheet metal when bending. The last input to the neural network is represented by tensile strength $R_{m}$. According to its general definition, tensile strength is considered a mechanical property of the material defining the size of the force or load at which the material is deformed permanently.

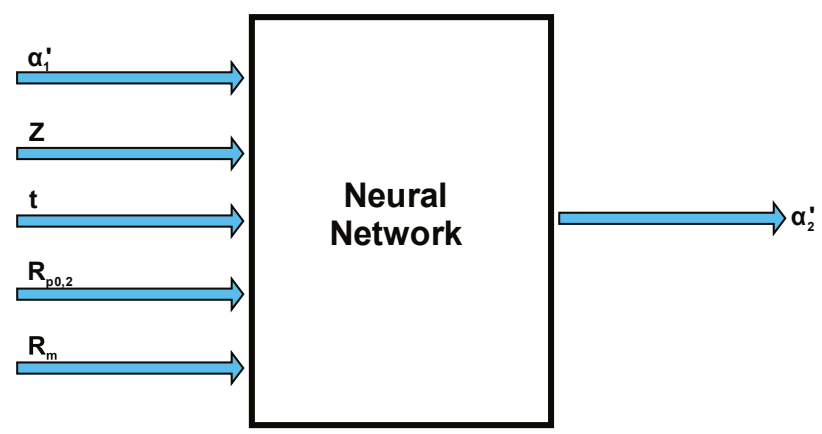

Figure 6 Diagram of inputs and outputs of the neural network for predicting the final bend angle 


\subsection{Neural network for predicting the final bend angle $\alpha_{2}{ }^{\prime}$}

A neural network with five inputs and one output was used for predicting the value of the final bend angle. A diagram of the mentioned neural network is shown in Fig. 6.

The output from the neural network $\alpha_{2}^{\prime}$ means the predicted final bend angle at given parameters of the prebending angle, die shift in the second bend, sheet thickness, yield stress and tensile strength.

\subsection{Neural network training}

The reliability of predictions using neural networks depends on their training. More examples in the learning database provide for greater reliability of the system $[21 \div 25]$. The training database consists of data obtained by means of experiments on the test tool. The database created on the basis of performed tests on the test tool is very reliable and representative at the same time, but only when the obtained test results are critically assessed. A specific part of training data required to teach the neural network are given in Tab. 4.

Table 4 The more relevant part of the data for training and testing the neural network

\begin{tabular}{|c|c|c|c|c|c|c|}
\hline \multirow{2}{*}{ 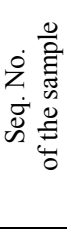 } & \multicolumn{5}{|c|}{ Inputs to the neural network (NN) } & \multirow{2}{*}{ 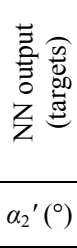 } \\
\hline & $\begin{array}{l}\alpha_{1}^{\prime} \\
\left(^{\circ}\right)\end{array}$ & $Z(\mathrm{~mm})$ & $t(\mathrm{~mm})$ & $R_{p 0,2}(\mathrm{MPa})$ & $R_{m}(\mathrm{MPa})$ & \\
\hline 1 & 13,7 & 2,9 & 1 & 1128,1 & 1326,8 & 77,3 \\
\hline 10 & 638 & 29 & 1 & 11281 & 13268 & 869 \\
\hline 11 & 65,2 & 3,9 & 1 & 1128,1 & 1326,8 & 90,4 \\
\hline 22 & 40,75 & 3,7 & 1,5 & 152 & 298,4 & 89,25 \\
\hline 23 & 43 & 3,6 & 1,5 & 152 & 298,4 & 89,7 \\
\hline 24 & 45,8 & 3,6 & 1,5 & 152 & 298,4 & 89,8 \\
\hline 29 & 69,25 & 3,35 & 1,5 & 152 & 298,4 & 91,75 \\
\hline 57 & 46,3 & 2,9 & 1 & 140 & 270 & 90,4 \\
\hline
\end{tabular}

Training and testing of the neural network was carried out on 68 samples. It should be noted that the system has been designed to be suitable for training the neural network by implementing a database for different values of the input data $[26 \div 30]$.

In relation to Tab. 4 , the measurements listed under sequence numbers 22,29 and 57 are excluded from the learning database as they are later used for testing the system. These three measurements were selected randomly by using the neural network and represent $5 \%$ out of the total 68 samples. So, the total amount of learning samples was 65 as the three randomly selected samples were intended for testing of the neural network.

For example, the training data under the sequence number 24 of the Tab. 4 is presented. In this learning event, the desired output (target) takes the following form:
- Output vector (target) for the final bend angle $\alpha_{2}{ }^{\prime}$ at $\alpha_{1}{ }^{\prime}=45,8^{\circ}, Z=3,6 \mathrm{~mm}, t=1,5 \mathrm{~mm}, R_{p 0,2}=152 \mathrm{MPa}$, $R_{m}=298,4 \mathrm{MPa}$ and $T_{\alpha 2^{\prime}}=89,8^{\circ}$.

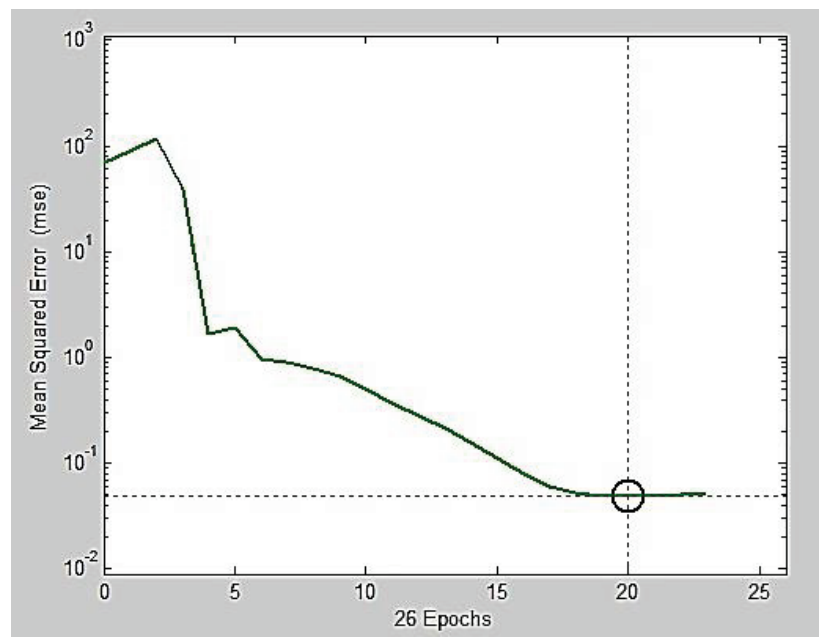

Figure 7 Diagram showing e-learning performance of the neural network by presenting the convergence of the learning error

Prediction of the final bend angle in the process of bending over two stages was performed by using a feedforward neural network with one hidden layer. The input layer of the neural network has five neurons (five inputs). There are ten neurons in the hidden layer and one neuron in the output layer. In the end, there is one output from the neural network representing the predicted final bend angle. A part of the learning database, which was used to train the neural network, is shown in Tab. 4. The learning performance of the neural network is graphically shown in Fig. 7, which also shows how the mean square deviation from the real value decreased with every learning step. The diagram in Fig. 7 shows that the learning error amounted to 0,04 at the twentieth step.

The application was entirely implemented in the Matlab R2009b development environment.

\subsection{System testing with real experiments on the tool}

Testing of the system was done in a way that adequate parameters of sheet metal bending over two stages were predicted using the neural network, which were then verified by practical tests on the test tool.

Selection and determination of the input data for predicting the final bend angle are described below. The input data to the neural network must be written in a specific sequence. The value of the final bend angle is predicted by the output from the neural network. Both, the input and the output values of the neural network are used when setting up the test tool, in order to achieve the desired or required final bend. Setting of individual parameters or values on the test tool must be accurate in order to obtain the desired or predicted values. When testing the predicted final bend angle, the sheet metal is first pre-bent to a certain value. Then, the shift of the die is set for the second bending. When predicting and testing the final bend angle on the tool, the input data are determined first and then the predicted final bend angle is obtained at the output, usually ranging between $77,3^{\circ}$ and $93,3^{\circ}$. 
Testing of the final bend angle on the tool for bending sheet metal over two stages, and before that, its prediction using the neural network is given in Tab. 5 .
The error between the predicted results using neural network shown in Tab. 5, and the tests carried out on the test tool for the final bend angle amounted to $0,01^{\circ}$.

Table 5 Values of predicting and testing on the tool for the final bend angles $\alpha_{2}{ }^{\prime}$

\begin{tabular}{|c|c|c|c|c|c|c|c|c|c|}
\hline \multirow{2}{*}{$\begin{array}{l}\text { Seq. } \\
\text { No. }\end{array}$} & \multirow{2}{*}{ Material } & \multicolumn{5}{|c|}{ Input of the neural network (NN) } & \multirow{2}{*}{$\begin{array}{l}\text { Output of the } \\
\text { NN } \alpha_{2}^{\prime}\left(^{\circ}\right)\end{array}$} & \multirow{2}{*}{$\begin{array}{c}\text { Tests on the tool } \\
\alpha_{2}{ }^{\prime}\left({ }^{\circ}\right)\end{array}$} & \multirow{2}{*}{$\begin{array}{c}\text { Difference } \\
\left.\alpha_{2}{ }^{\prime}{ }^{\circ}\right) \\
\end{array}$} \\
\hline & & $\alpha_{1}^{\prime}\left(^{\circ}\right)$ & $Z(\mathrm{~mm})$ & $t(\mathrm{~mm})$ & $R_{p 0,2}(\mathrm{MPa})$ & $R_{m}(\mathrm{MPa})$ & & & \\
\hline 1 & DX $52 \mathrm{D}+\mathrm{Z}(1 \mathrm{~mm})$ & 60 & 2,9 & 1 & 140 & 270 & 90,24 & 90,25 & 0,01 \\
\hline 2 & DC06 $(1,5 \mathrm{~mm})$ & 65 & 3,45 & 1,5 & 152 & 298,4 & 90,41 & 90,42 & 0,01 \\
\hline 3 & HX340LAD $(0,8 \mathrm{~mm})$ & 50 & 2,75 & 0,8 & 323 & 433,7 & 90,56 & 90,56 & 0 \\
\hline 4 & Docol 1200M (1 mm) & 70 & 3,9 & 1 & 1128,1 & 1326,8 & 90,65 & 90,65 & 0 \\
\hline
\end{tabular}

The results of the predictions proved to be sufficiently reliable because there were no major discrepancies between the predicted results and the results obtained by testing on the test tool. It can be concluded that the systems and neural networks predict the final bend angle well.

\section{Conclusion}

The presented intelligent method for predicting the final bend angle is universal, applicable in practice and allows for further upgrading and scientific analysis. From a scientific point of view as well as from the perspective of its application in practice, it is particularly important that the collected data are real and considered on the test tool for bending sheet metal over two stages. In practice, the intelligent method for predicting the final bend angle enables a reduction of the number of tests of sheet metal bending in particular, as well as the need for prior technical knowledge of sheet metal bending. This system of intelligently predicting the final bend angle is simple, robust, user-friendly and cost-effective. Further research into sheet metal bending over two stages would be particularly meaningful towards expanding the existing database for training with more different types of sheet metal. A more extensive database would further enhance the usefulness and reliability of the system. Future research could include modifying or searching for other potential influential quantities, which could have a significant impact on the process of bending sheet metal over two stages itself. In view of further research it would also be possible to modify or adjust the individual tool parameter settings and improve the construction of the test tool.

\section{Acknowledgements}

Special thanks go to Dr. David Potocnik and all employees of the Laboratory for Intelligent Manufacturing Systems and the Laboratory for Flexible Manufacturing Systems at the University of Maribor.

\section{References}

[1] Pahole, I.; Bonifarti, S.; Ficko, M.; Vaupotic, B.; Kovacic, S.; Balic, J. Bending of sheet metal of complicated shapes (for $90^{\circ}$ angle and more) in combined tools. // Journal of Achievements in Material Manufacturing Engineering. 16, 1/2(2006), pp. 88-93.

[2] Oehler, G. Schnitt-, Stanz- und Ziehwerkzeuge, 7, Auflage. Springer-Verlag Berlin Heidelberg, Berlin, 1993. DOI: 10.1007/978-3-642-97498-4
[3] Brezocnik, M.; Balic, J.; Kampus, Z. Modeling of forming efficiency using genetic programming. // Journal of Materials Processing Technology, (Print ed.). 109, 1/2(2001), pp. 20-29.

[4] Starman, B.; Vrh, M.; Halilovič, M.; Štok, B. Advanced Modelling of Sheet Metal Forming Considering Anisotropy and Young's Modulus Evolution. // Strojniški vestnik Journal of Mechanical Engineering. 60, 2(2014), pp. 84-92. DOI: $10.5545 /$ sv-jme.2013.1349

[5] Adamovic, D.; Mandic, V.; Jurkovic, Z.; Grizelj, B.; Stefanovic, M.; Marinkovic, T.; Aleksandrovic, S. An experimental modelling and numerical FE analysis of steelstrip ironing process. // Tehnički vjesnik-Technical Gazette, 17, 4(2010), pp. 435-444.

[6] Math, M. Finite Element Study and Simulation of Plate Bending Process. // International Journal of Simulation Modelling. 1, 1(2001), pp. 31-40.

[7] Plančak, M.; Car, Z.; Kršulja, M.; Vilotić, D.; Kačmarčik, I.; Movrin, D. Possibilities to measure contact friction in bulk metal forming. // Tehnički vjesnik-Technical Gazette. 19, 4(2012), pp. 727-734.

[8] Milutinović, M.; Vilotić, D.; TomažPepelnjak, T. Part dimensional errors in free upsetting due to the elastic springback. // Tehnički vjesnik-Technical Gazette. 21, 1(2014), pp. 135-140.

[9] Gardiner, A. G. The springback of metals. // Trans. ASME, Journal of Applied Mechanics. 79, (1957), pp. 1-9.

[10] Ling, Y. E.; Lee, H. P.; Cheok, B. T. Finite element analysis of springback in L-bending of sheet metal. // Journal of Materials Processing Technology. 168, 2(2005), pp. 296-302. DOI: 10.1016/j.jmatprotec.2005.02.236

[11] Johnson, W.; Yu T. X. Springback after the biaxial elasticplastic pure bending of a rectangular plate - I. // International Journal of Mechanical Sciences. 23, 10 (1981), pp. 619-630. DOI: 10.1016/0020-7403(81)90042-4

[12] Davies, R. J.; Liu Y. C. Control of springback in flanging operation. // Journal of Applied Metalworking. 3, 2(1984), pp. 142-147. DOI: $10.1007 / B F 02833693$

[13] Wang, N. M. Predicting the effect of die gap on flange spring back. // Proceedings of the International Deep Drawing Research Group Congress (13th Biennial IDDRG Congress), Melbourne, Australia, 1984.

[14] Nagtegaal, J. C.; Taylor, L. M. Comparison of implicit and explicit finite element methods for analysis of sheet forming problems FE-Simulation of 3-D Sheet Metal Forming Processes in Automotive Industry. // 894. VDI, Berichte. (1991), pp. 705-725.

[15] Livatyali, H.; Altan, T. Prediction and elimination of springback in straight flanging using computer aided design methods: Part 1 - Experimental investigations. // Journal of Materials Processing Technology. 117, 1-2(2001), pp. 262268.

[16] Karafillis, A. P.; Boyce, M. C. Tooling design in sheet metal forming using springback calculations. // International Journal of Mechanical Sciences. 34, 2(1992), pp. 113-131. DOI: 10.1016/0020-7403(92)90077-T

[17] Bammer, F.; Schumi, T.; Otto, A.; Schuöcker, D. Laser assisted bending for efficient light-weight-production. // 
Tehnički vjesnik-Technical Gazette. 18, 4(2011), pp. 571576.

[18] Docol, M. Cold reduced martensitic steels. SSAB AB SWEDEN. URL:http://www.ssab.com/Global/DOCOL/ datasheets_docol/en/207_Docol\%20M.pdf. (16.01.2013).

[19] Deep-drawing steels DD, DX and DC - Steels for complex forming requirements. Thyssen Krupp Steel Europe AG. URL:http:/www.thyssenkrupp-steeleurope.com/tiny/Gv/ download.pdf. (18.01.2013).

[20] HX340LAD Steels with high yield strength for cold forming - micro-alloyed.Salzgitter Flachstahl $\mathrm{GmbH}$. URL:http://www.salzgitter-flachstahl.de/MDB/

downloadcenter_en/Product range_Hot_dipped galvanised _steels_products/Micro_alloyed_steel_grades_with_high_y ield strength for cold forming/HX340LAD edition 052 $012^{-} \cdot(21.01 . \overline{2} 01 \overline{3})$.

[21] Klancnik, S.; Balic, J.; Cus, F. Intelligent prediction of milling strategy using neural networks. // Control and Cybernetics. 39, 1(2010), pp. 9-22.

[22] Saric, T.; Simunovic, G.; Simunovic, K. Use of Neural Networks in Prediction and Simulation of Steel Surface Roughness. // International Journal of Simulation Modelling. 12, 4(2013), pp. 225-236. DOl: 10.2507/IJSIMM12(4)2.241

[23] Klancnik, S.; Senveter, J. Computer-based workpiece detection on CNC milling machine tools using optical camera and neural networks. // Advances in Production Engineering \& Management. 5, 1(2010), pp. 59-68

[24] Ćosić, P.; Lisjak, D.; Antolić, D. Regression analysis and neural networks as methods for production time estimation. // Tehnički vjesnik-Technical Gazette. 18, 4(2011), pp. 479484.

[25] Hachicha, W. A Simulation Metamodelling Based Neural Networks for Lot-Sizing Problem in MTO Sector. // International Journal of Simulation Modelling. 10, 4(2011), pp. 191-203. DOI: 10.2507/IJSIMM10(4)3.188

[26] Senveter, J.; Klancnik, S.; Balic, J.; Cus, F. Prediction of surface roughness using a feed-forward neural network. // Management and production engineering review. 1, 2(2010), pp. 47-55.

[27] Mocnik, D.; Paulic, M.; Klancnik, S.; Balic, J. Prediction of dimensional deviation of workpiece using regression, ANN and PSO models in turning operation. // TehničkivjesnikTechnical Gazette, 21, 1(2014), pp. 55-62.

[28] Žilková, J.; Timko, J. \&Girovský, P. Modelling and Control of Tinning Line Entry Section Using Neural Networks. // International Journal of Simulation Modelling. 11, 2(2012), pp. 97-109. DOI: 10.2507/IJSIMM11(2)4.210

[29] Hrelja, M.; Klancnik, S.; Balic, J.; Brezocnik, M. Modelling of a Turning Process Using the Gravitational Search Algorithm. // International Journal of Simulation Modelling. 13, 1(2014), pp. 30-41. DOI: 10.2507/IJSIMM13(1)3.248

[30] Zuperl, U.; Cus, F.; Kiker, E. Intelligent adaptive cutting force control in end-milling. // Tehnički vjesnik-Technical Gazette. 13, 1,2(2006), pp. 15-22.

\section{Authors' addresses}

Jernej Senveter, BSc

University of Maribor

Faculty of Mechanical Engineering

Smetanova ulica 17, 2000 Maribor, Slovenia

E-mail: jernej.senveter@gmail.com

Joze Balic, PhD

University of Maribor,

Faculty of Mechanical Engineering,

Smetanova ulica 17, 2000 Maribor, Slovenia

E-mail: joze.balic@um.si

\section{Mirko Ficko, PhD}

University of Maribor

Faculty of Mechanical Engineering

Smetanova ulica 17, 2000 Maribor, Slovenia

E-mail: mirko.ficko@um.si

\section{Simon Klancnik, PhD}

University of Maribor

Faculty of Mechanical Engineering

Smetanova ulica 17, 2000 Maribor, Slovenia

E-mail: simon.klancnik@um.si 